\title{
Composition of uranite and chalkolite
}

\section{Werther}

To cite this article: M. Werther (1848) Composition of uranite and chalkolite, Philosophical Magazine Series 3, 33:223, 397-398, DOI: 10.1080/14786444808646129

To link to this article: http://dx.doi.org/10.1080/14786444808646129

册 Published online: 30 Apr 2009.

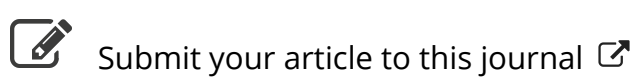

Џll Article views: 2

Q View related articles $₫$ 
lysis is rather too small; but similar errors are inevitable with bodies which are uncrystallizable and difficult to burn. M. Arppe obtained still less carbon $(61 \cdot 2)$ than the authors.

Boiling nitric acid attacks sulphomorphide and forms sulphuric acid; water added to the solution precipitates a yellow flocculent matter, soluble in ammonia. As no gas is liberated during the formation of sulphomorphide, and as the sulphuric liquid contains no other substance, the formula given seems sufficiently controlled by the preceding analysis.

Sulphonarcotide.-When narcotina moistened with water is heated with a slight excess of sulphuric acid, a solution is obtained which becomes of a deep brown colour when more strongly heated, and eventually thickens. No gas is liberated during this reaction; the mixture is to be diluted with water and boiled, thrown on a filter and washed with cold water, in which it appears to be insoluble. It dissolves in alcohol, but it is not deposited from it in crystals.

This product behaves like sulphomorphide; when calcined on platina foil, it yields much charcoal very difficult to burn; subjected to distillation, it yields water and oily matter of a foetid odour. By analysis 100 parts yielded

$$
\begin{array}{lr}
\text { Carbon ....... } & 59 \cdot 1 \\
\text { Hydrogen .... } & 5 \cdot 3 \\
\text { Sulphur . . . . } & 3 \cdot 6
\end{array}
$$

These correspond to a formula represented by neutral sulphate of narcotina, minus two equivs. of water, $\mathrm{SO}^{4}\left(\mathrm{H}^{2}, 2 \mathrm{C}^{93} \mathrm{H}^{25} \mathrm{NO}^{7}\right)-2 \mathrm{OH}^{2}$. This formula requires-

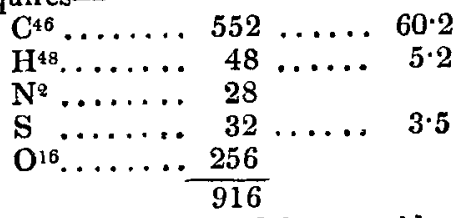

Ammonia does not act upon sulphonarcotide, potash dissolves it with a brown colour, and acids separate in the green state. When boiled with nitric acid, sulphonarcotide gives sulphuric acid, and also a yellow matter soluble in ammonia.

Sulphomorphide and sulphonarcotide evidently belong to the same class of bodies as the amides and the anilides; they are to the sulphates of morphia and narcotina, what sulphamide and sulphanilide are to the sulphates of ammonia and aniline. Certainly it has not been possible to separate morphia and narcotina from them; but it must be remembered, that with respect to the anilides this regeneration requires the intervention of a high temperature, and that this necessarily acts destructively on non-volatile alkaloids, like morphia and narcotina.-Ann. de Ch. et de Phys., Septembre 1848.

\section{COMPOSITION OF URANITE AND CHALKOLITE. BY M. WERTHER.}

The specimen analysed by $M$. Werther was from Gunnislake Mine, Cornwall. He operated on a well-crystallized specimen. His results were as follows:- 


\begin{tabular}{|c|c|c|c|}
\hline & I. & $\begin{array}{l}\text { II. } \\
13.52\end{array}$ & $\begin{array}{l}\text { III. } \\
14^{\circ} 40\end{array}$ \\
\hline Oxide of uranium $\ldots$ & $\begin{array}{l}1501 \\
58.45\end{array}$ & $57 \cdot 20$ & $60 \cdot 80$ \\
\hline Oxide of copper ...... & & & $8 \cdot 27$ \\
\hline Water . . . . . . . . . & $15 \cdot 22$ & $15 \cdot 55$ & \\
\hline Silica $\ldots \ldots \ldots \ldots$ & & $0 \cdot 49$ & \\
\hline Earthy matter. . . . . . & & 0.61 & 0.22 \\
\hline
\end{tabular}

The formula deduced from these analyses is

$\left[\mathrm{P}^{2} \mathrm{O}^{5}, \mathrm{Cu}^{2} \mathrm{O}, 2 \mathrm{U}^{2} \mathrm{O}^{2} \mathrm{O}+8 \mathrm{aq}\right]$.

The uranite of Autun gave the following results :-

$\begin{array}{lr}\text { Phosphoric acid. . . . . . . . } & 14 \cdot 00 \\ \text { Oxide of uranium . . . . . . . } & 63 \cdot 28 \\ \text { Lime } \ldots \ldots \ldots \ldots \ldots \ldots \ldots & 5.86 \\ \text { Barytes } \ldots \ldots \ldots \ldots \ldots \ldots \ldots & 1.03 \\ \text { Water } \ldots \ldots \ldots \ldots \ldots \ldots \ldots & 14.30\end{array}$

Uranite has therefore a composition similar to that of chalkolite, its formula being $\left[\mathrm{P}^{2} \mathrm{O}^{5}, \mathrm{Ca}^{2} \mathrm{O}, 2 \mathrm{U}^{2} \mathrm{O}^{2} \mathrm{O}+8 \mathrm{aq}\right]$. It is to be observed that the formula long since proposed by M. Berzelius agrees exactly with that of $M$. Werther.

M. Werther obtained chalkolite artificially by the following process :- He took the salt of uranium $\left[\mathrm{P}^{2} \mathrm{O}^{5}, \mathrm{H}^{2} \mathrm{O}, 2 \mathrm{U}^{2} \mathrm{O}^{2} \mathrm{O}+8 \mathrm{aq}\right]$, and boiled it for some time with a solution of subacetate of copper, decanted the liquid, digested the residue with acetic acid, and washed it perfectly: he thus obtained a greenish powder, which presented by the microscope the unaltered crystals of the phosphate of uranium which he had employed. This product contained $14 \cdot 6$ per cent. of water, and 8.7 per cent. of oxide of copper.-Journ. de Ph. et de Ch., Juillet 1848.

\section{SOCIETY OF THE FRIENDS OF THE NATURAL SCIENCES OF VIENNA.}

The Wiener Zeitung of the 28th September last contains a report of the proceedings of a Meeting held at the Imperial Mint of Vienna, on the 22nd of the same month, at which Bergrath Haidinger presided.

The President communicated to the Meeting that his application to the Government respecting the formation of a Society of the Natural Sciences had received the following favourable answer:"According to an announcement made by the Minister of the Interior on the 22nd of July of the present year, His Majesty the Emperor and King, by a Decree of the 18th of July, has been graciously pleased to sanction the formation of the Society proposed by you, under the appellation of The Society of the Friends of the $\mathrm{Na}$ tural Sciences of Vienna (Gesellschaft der Freunde der Naturwissenschaften in Wien)." Circumstances inevitably resulting from the existing state of affairs, and the summer-months during which so many scientific men and others interested are absent from the capital, render it unavoidable to postpone for a time the General Meeting which is necessary to be held for the formal constitution of the Society. Notice of this Meeting will be duly given.

This communication was preceded by several others of a scientific 